\title{
Edukacja międzykulturowa na dużą odległość: edukacyjne i ekologiczne działania czeskiego wolontariatu w Ladakhu
}

\begin{abstract}
Streszczenie: Artykuł przedstawia działalność edukacyjną czeskich aktywistów z ekologicznego ruchu Brontosaurus, którzy od kilkunastu lat budują szkołę w jednej z wiosek w Ladakhu w północnych Indiach. Sami w niej też nauczają - przeważnie miejscowych nauczycieli. Prywatna szkoła pod patronatem czeskiej organizacji wyraźnie poprawiła ofertę edukacyjną wioski Mulbekh i jej okolic. I choć jest dostępna tylko dla części miejscowych dzieci, kształci, używając coraz bardziej nowoczesnych i skutecznych metod edukacyjnych. Czescy wolontariusze zdają sobie sprawę z możliwych zagrożeń wynikających z dystansu kulturowego i dlatego starają się działać zgodnie z precyzyjnie określonymi zasadami, które minimalizują te niebezpieczeństwa.
\end{abstract}

Słowa kluczowe: edukacja międzykulturowa, wolontariat, wolontariat edukacyjny, dystans kulturowy, Czesi w Himalajach, Ladakh

\section{Edukacyjny wolontariat}

Pomoc społeczeństwom, które nie rozwijają się tak szybko i w takim samym kierunku jak nasza atlantycka cywilizacja, jest naszym obowiązkiem. A najlepszym wariantem takiej pomocy - ze względu na niezamożność obszarów rozwijających się - jest wolontariat, czyli pomoc nieodpłatna. Każdy wolontariat jest mile widziany i nikt, kto uważa się za humanistę, nie odważyłby się go kwestionować. A jeżeli w wolontariacie chodzi nie tyle o doraźną pomoc materialną, lecz o ponadczasowe doskonalenie miejscowego społeczeństwa poprzez udostępnienie mu wykształcenia, co do jego wartości nie ma żadnych wątpliwości.

Wolontariat edukacyjny jest w naszej cywilizacji jednym z najbardziej docenianych. A ponieważ wolontariat taki związany jest $\mathrm{z}$ wyjazdami do nie- 
raz bardzo odległych krańców świata, motywuje m.in. tych wolontariuszy, którzy oprócz pomocy potrzebującym liczą na zaspokojenie własnej chęci zwiedzania świata. Takie połączenie motywacji nie jest naganne, ponieważ daje w sumie pozytywne efekty. W teorii turystyki zjawisko to funkcjonuje w postaci tzw. turystyki wolontariatu (volunteer tourism) (Callanaan i Thomas, 2005). Czy jednak taka pomoc jest skuteczna pomimo bardzo dużej odległości między kulturą potrzebujących pomocy a kulturą niosących pomoc? Czy nie powoduje skutków ubocznych, które niwelują w swoim efekcie pozytywne konsekwencje podniesienia poziomu wykształcenia? Na te pytania próbuje odpowiedzieć niniejszy artykuł. Jego treścią jest opis działalności czeskiej organizacji pozarządowej Brontosaurus, która od kilkunastu lat pomaga w rozbudowie i unowocześnianiu szkoły w małej wiosce w Ladakhu, prowadzi tam zajęcia i przygotowuje miejscowych nauczycieli.

\section{Ladakh - peryferia świata}

Gdzie leży Ladakh? Pytanie to nie zaskoczy chyba tylko geografów i miłośników Himalajów i Tybetu. Jest to jeden z najtrudniej dostępnych obszarów Kaszmiru w północnych Indiach. Leży na wschodzie u podnóża Himalajów w dorzeczu górnego Indusu na granicy z Chinami (konkretnie z Tybetem) i z Pakistanem. Najwyższe szczyty sięgają 7000 m najniżej położone miejsce, w którym Indus wypływa z Ladakhu do pakistańskiej części Kaszmiru, leży na wysokości $2600 \mathrm{~m}$.

Jest to nieprzystępny wysokogórski obszar, który dawniej w miesiącach zimowych był z powodu śniegu zupełnie odcięty od świata. Jedyne naturalne połączenie Ladakhu z resztą świata tworzy rzeka Indus. Jej źródła leżą w Tybecie i płynie przez Ladakh początkowo na północny zachód. Indus płynie potem dalej przez północny Kaszmir, gdzie zatacza olbrzymi łuk na południowy zachód i płynie przez cały Pakistan aż do ujścia w Zatoce Bengalskiej. Niestety ten najbardziej naturalny szlak komunikacyjny jest od 70 lat nieprzejezdny. Ladakh jest bowiem częścią Kaszmiru należącą do Indii, natomiast Kaszmir północno-zachodni należy do Pakistanu. Od indyjsko-pakistańskiej wojny o Kaszmir z roku 1948 jest to nieprzekraczalna granica dwóch wrogo do siebie nastawionych państw. Połączenie z resztą indyjskiego Kaszmiru jest dla Ladakhu bardzo ważne, ale prowadzi przez wysokie górskie przełęcze: Fotu La (4108 m), Namika La (3700 m) i Zoji La (3528 m), które zimą są nieprzejezdne (Keatinge, 1993). Na północnym wschodzie granicę z rzadko zaludnionym Tybetem tworzy główny grzbiet Himalajów. 
Powierzchnia Ladakhu zmieniała się w historii. W XVII wieku był częścią Tybetu i jego powierzchnia była większa. Na początku XX wieku - jako część Indii Brytyjskich - zajmował $118523 \mathrm{~km}^{2}$, a aktualnie ta jego część, która wchodzi w skład Indii, ma powierzchnię 86904 km². Ok. 30 tys. km² północnego Ladakhu opanowanych jest przez Pakistan. Dawne wschodnie peryferie Ladakhu o powierzchni ok. 37 tys. $\mathrm{km}^{2}$ (znane dziś jako Aksai Chin) są obszarem spornym między Chinami a Indiami, który jednak faktycznie jest opanowany przez Chińczyków (Lamb, 1973).

Indyjską część Ladakhu zamieszkuje obecnie ok. 270 tys. mieszkańców. W odróżnieniu od większości regionów azjatyckich, liczba ludności nie rośnie zbyt szybko. Sto lat temu tereny te zamieszkiwało 183 tys. mieszkańców. W ubiegłym wieku liczba mieszkańców wzrosła o niecałe $50 \%$, podczas kiedy liczba mieszkańców całych Indii czy Chin wzrosła w tym samym czasie 4-5-krotnie. Większość ludności mieszka na wsi. Miast jest niewiele i są bardzo małe. Największymi są Leh (27 tys. w roku 2001) i Kargill (10 tys. w roku 2001).

W ciągu całej długiej historii przeważającą grupą etniczną w Ladakhu byli Tybetańczycy posługujący się dialektem tybetańskim i piszący tybetańskim alfabetem. Są wyznawcami buddyzmu lamaistycznego i koncentrują się w centralnej części regionu w powiecie Leh. Mniejszościami religijnymi w Ladakhu byli hinduiści oraz muzułmanie (w 95\% szyici) - ale ci ostatni wykazują szybszy wzrost populacji i dziś już zrównali się liczebnie z buddystami. Miejscowi muzułmanie tradycyjnie koncentrują się w powiecie Kargill w pobliżu dzisiejszej granicy z Pakistanem. W Ladakhu jest obecna także niewielka społeczność chrześcijan - są to członkowie protestanckiego kościoła Braci Morawskich, których misja działa w Ladakhu od 1885 roku (Bray, 1985). Pomimo religijnej różnorodności Ladakh postrzegany jest jako region o długotrwałej dominacji buddyzmu, w związku z czym nazywany jest Małym Tybetem.

Ladakh był z Tybetem od wieków związany także politycznie, ale dzięki swojemu peryferyjnemu położeniu i dużej odległości od głównych ośrodków tybetańskiej kultury przynależność ta była raczej formalna. W XVIII wieku i na początku wieku XIX Ladakh był faktycznie niepodległy. W 1839 roku został przyłączony do Kaszmiru i razem z nim znalazł się w roku 1846 w sferze wpływów Wielkiej Brytanii. Ale i ta zależność była, dzięki niedostępności regionu, raczej formalna.

W roku 1947 kolonialna władza Brytyjczyków nad Półwyspem Indyjskim skończyła się i nowo powstałe niepodległe Indie i Pakistan rozpoczęły wojnę 
o Kaszmir, gdzie większość mieszkańców była muzułmańska, czyli propakistańska, ale władza była hinduistyczna, czyli proindyjska. Wojna zakończyła się w styczniu 1948 roku rozejmem, w wyniku którego Ladakh znalazł się w Indiach, a jego północna część w Pakistanie i dzisiaj należy do prowincji Baltistan. Od tego czasu walki kilkakrotnie wybuchały na nowo: w latach 1965, 1971 i 1999, ale linia demarkacyjna nie uległa zmianie, pilnowana przez jednostki ONZ. Linia demarkacyjna, która do pewnego stopnia przypomina linię frontu - tyle że chwilowo bez walki - zamyka najłatwiejszą, naturalną drogę z Ladakhu do doliny Indusu, co jeszcze bardziej pogłębiło jego odcięcie od świata.

Władze Indii postanowiły więc otworzyć nową drogę do Ladakhu, która by omijała tereny zajęte przez Pakistańczyków. Rozpoczęły rozbudowę dawnego szlaku górskiego dla karawan, przejezdnego dotychczas na mułach i tylko w miesiącach letnich. Pierwszy samochód dotarł do muzułmańskiej części Ladakhu pod zarządem Indii, do miejscowości Kargill, w połowie lat 50. XX wieku, a drogę ze stolicy Kaszmiru - Szrinagaru - zbudowano tam w roku 1964 (Keatinge, 1993). Bliskość linii demarkacyjnej między armią indyjską i pakistańską i faktycznie ciągły stan wojenny były przyczyną zamknięcia regionu dla cudzoziemców. Aż do roku 1974 w Ladakhu praktycznie nie było żadnych turystów. Władze Indii dopiero wówczas zdecydowały się na otwarcie Ladakhu dla turystów, w tym zagranicznych. Zaraz w pierwszym roku skorzystali z tego orientaliści David Snellgrove (1920-2016) i Tadeusz Skorupski (ur. 1945). Przeprowadzili w Ladakhu pierwsze od czasów panowania brytyjskiego badania miejscowej kultury (Snellgrove i Skorupski, 1977). Prawdziwe otwarcie na świat i napływ turystów do Ladakhu nastąpiły jednak dopiero po uruchomieniu połączenia lotniczego w roku 1978 (Prem, 1994). Lotnisko w Leh - jedno z najwyżej położonych na świecie (3256 m) - jest bowiem nadal jedynym połączeniem Ladakhu ze światem w miesiącach zimowych. Drogi zbudowane w latach 60. ubiegłego wieku z Ladakhu do centralnego Kaszmiru oraz do Manali w północnoindyjskim stanie Himaczal-Pradesz są nieprzejezdne, kiedy spadnie śnieg.

\section{Czeska organizacja Brontosaurus w Himalajach}

Brontosaurus jest pozarządową czeską organizacją ekologiczną, która powstała w 1974 roku, ogłoszonym przez ONZ Rokiem środowiska naturalnego (Sarre i Jehlicka, 2007). Inicjatorem powstania ruchu w ówczesnej Czechosłowacji był redaktor popularnego czasopisma „Mladý světo” (Młody świat) 
Josef Velek (1939-1990). Czasopismo ukazywało się w dużym nakładzie i chociaż było ograniczane politycznymi wytycznymi rządzącej wówczas partii komunistycznej, bynajmniej nie należało do dogmatycznych. Nazwę Brontosaurus wzięto od jednego z gatunków dinozaura, dziś już nieużywanej. Założyciele ruchu stworzyli slogan „Brontosaur nie przeżył, ponieważ przerósł swoje możliwości” zgodnie z ówczesną teorią na temat wyginięcia dinozaurów. Nowy ruch działał w ideologicznie neutralnej sferze ochrony środowiska, ale musiał stale uważać, aby nie przekroczyć pewnych barier, które mogły spowodować zakaz jego działalności. Warto to przypomnieć, ponieważ pokonywanie tego typu przeszkód jest dziś trudne do wyobrażenia.

Ruch Brontosaurus istnieje nadal i stale zajmuje się ochroną przyrody oraz edukacją na rzecz ekologii. Skupia w Republice Czeskiej ponad 1000 członków zorganizowanych w kilkunastu oddziałach regionalnych. Jedną z jego sekcji jest grupa „Brontosaurus w Himalajach”, która ukształtowała się w trakcie pobytów edukacyjno-roboczych pod nazwą Skrajne Granice organizowanych od roku $2006 \mathrm{w}$ indyjskim Ladakhu. Pierwotnie chodziło o tradycyjny program ruchu Brontosaurus, tzn. o pożyteczne spędzanie czasu wolnego dla młodzieży, dokształcanie i aktywny udział w pracach na rzecz ochrony zabytków kultury - w tym przypadku miejscowych klasztorów buddyjskich (Brontosaurus v Himálájích).

Uczestnicy pobytów wkrótce zorientowali się, że region Ladakhu ma ogromne potrzeby edukacyjne, które sam zaspokaja tylko w ograniczonym zakresie i dlatego od roku 2008 wyjazdy w Himalaje przerodziły się w regularną współpracę na rzecz wspierania procesu kształcenia miejscowej młodzieży. Tak powstał projekt La Ngonpo (Błękitna Przełęcz), zakładający stworzenie internetowego połączenia między wybranymi szkołami w Czechach i w Ladakhu. Najbardziej konkretny kształt zaangażowania na miejscu przybrała stała współpraca ze szkołą w wiosce Mulbekh. Jest to ostatnia buddyjska wioska w przeważnie muzułmańskim powiecie Kargill. Leży na wysokości ok. $3450 \mathrm{~m}$ i znana jest dzięki dwu klasztorom buddyjskim (jeden ze szkoły Drukpa, drugi z młodszej szkoły Gelugpa). W ich pobliżu w skale wyrzeźbiono - prawdopodobnie w VII lub VIII wieku - wysoką na $9 \mathrm{~m}$ statuę Buddy, która jest od otwarcia Ladakhu dla turystów znaczącą atrakcją turystyczną.

W wiosce Mulbekh powstała w 1992 roku prywatna szkoła Spring Dales Public School mająca umożliwić edukację miejscowym dzieciom, które dotychczas miały możliwości kształcenia tylko w szkołach klasztornych i w państwowych, powstałych na bazie kolonialnej tradycji brytyjskiej. Ani szkoły 
klasztorne, ani indyjskie państwowe nie dawały możliwości powszechnego kształcenia i część miejscowych dzieci nadal pozostawała poza zasięgiem edukacji. Szkoła Spring Dales Public School początkowo nie przedstawiała wyższego poziomu kształcenia. Tylko część nauczycieli miała wykształcenie pedagogiczne i w sytuacji braku kadr za dostateczne było uważane jakiekolwiek wykształcenie wyższe. Nauczyciele byli najczęściej albo w wieku emerytalnym, albo bardzo młodzi, często pochodzący z innych regionów Indii, gdzie panowało bezrobocie.

W 2008 roku dyrektorem szkoły został miejscowy obywatel Tsewang Norboo, który postanowił ją rozbudować i udostępnić większej liczbie dzieci. Mniej więcej w tym samym czasie pojawili się w regionie członkowie czeskiego ruchu Brontosaurus, zainteresowani ekologią regionu i oferujący drobne prace restauratorskie w buddyjskich klasztorach. Zainteresowanie pomocą spotkało się z autentycznym zapotrzebowaniem. Jiří Sázel, kierownik działań ruchu Brontosaurus w Ladakhu od roku 2009, zaczął organizować gromadzenie środków finansowych i wysyłanie do szkoły czeskich nauczycieli-wolontariuszy.

W kolejnych latach do Ladakhu zaczęła regularnie jeździć stosunkowo duża liczba wolontariuszy, co doprowadziło do tego, że organizacja Brontosaurus w Himalajach rozrosła się i w roku 2012 usamodzielniła się i zaczęła występować pod własnym szyldem (Brontosaurus v Himálájích).

Dobrym punktem wyjścia na początku wolontariatu edukacyjnego była dobra marka szkoły Braci Morawskich w stolicy Ladakhu Leh, która była początkowo partnerem projektu La Ngonpo. Pomimo dużej odległości - Mulbekh leży w odległości $180 \mathrm{~km}$ od Leh - można było się powołać na pokrewieństwo z wyżej wymienionym kościołem, choć należy wyjaśnić, że Bracia Morawscy nie są Morawianami ani Czechami. Nazwa pochodzi od miejsca założenia jednego z kościołów protestanckich, ale sami Bracia Morawscy w Indiach są dziś etnicznymi Niemcami. Pierwsi misjonarze należący do Braci Morawskich pojawili się w Leh już w roku 1885. Założyli tam działającą do dziś szkołę i nawrócili niewielką liczbę mieszkańców Ladakhu na chrześcijaństwo (Bray, 1985). Nowi czescy wolontariusze z ruchu Brontosaurus mogli się odwołać m.in. do tego, że większość z nich, łącznie z kierownikiem Jiřím Sázelem, pochodziła z Moraw. Współpraca z niemieckimi „Morawianami” była jednak symboliczna, choć nie sposób wykluczyć, że sama marka regionu, z którego pochodzili ofiarodawcy pomocy, odegrała tu pewną pozytywną rolę. 


\section{Działania czeskich wolontariuszy na rzecz edukacji}

Decydując się na długotrwałą pomoc konkretnej społeczności, czescy wolontariusze określili kilka celów, które chcieliby przez to osiągnąć:

- poprawę wykształcenia dzieci w wiosce Mulbekh,

- zachowanie i rozwój kultury Małego Tybetu poprzez wykształcenie,

- krzewienie idei ekologicznej,

- wzajemną wymianę kulturową i pozytywną postawę wobec ludności i kultury Małego Tybetu,

- kształtowanie świadomości kulturowej i społecznej wszystkich uczestników pomocy - tych, którzy z niej korzystają, ale też tych, którzy pomagają.

Na czym polegają te działania w praktyce? Przede wszystkim na pozyskiwaniu pieniędzy. Ale nie w postaci prostych darowizn, lecz raczej w pomocy w pozyskiwaniu grantów. Dzięki pogłębiającej się współpracy w ramach projektu La Ngonpo udało się w latach 2010-2012 pozyskać wsparcie Komisji Europejskiej i czeskiego Ministerstwa Spraw Zagranicznych. Ruch pozyskuje też prywatnych darczyńców, a jednym z tych, którzy inicjatywę wspierają regularnie, jest duchowy przywódca Tybetu Dalajlama (Brontosaurus v Himálájích).

Najbardziej konkretną formą działalności ruchu Brontosaurus w Himalajach jest wspieranie konkretnej szkoły - chodzi właśnie o prywatną szkołę Spring Dales Public School. Czescy wolontariusze są przeważnie nauczycielami, którzy przyjeżdżają na krótkie kursy, odbywające się głównie latem, choć $\mathrm{w}$ ostatnich latach kilku $\mathrm{z}$ nich zostało w Mulbekh nawet $\mathrm{w}$ okresie zimowym. Ich zajęcia z uczniami są raczej pokazowe, a uczestnikami kursów są w pierwszej kolejności miejscowi nauczyciele. Chodzi o przekazanie wiedzy o nowoczesnych metodach nauczania, o dostosowaniu przerabianego materiału do poziomu rozwoju uczniów itp. Dotychczas tego bowiem nie było. Dzieci uczyły się przeważnie na pamięć, pracując nieraz z podręcznikami, które były albo niewystarczające, albo przerastały ich możliwości.

Czescy nauczyciele starają się rozpowszechnić w Ladakhu najnowocześniejsze metody nauczania. Pokazują miejscowym nauczycielom, młodzieży, a nawet dorosłym, jak pracować z nowoczesnymi pomocami dydaktycznymi, nie wyłączając komputerów. Pomagają tym samym wprowadzać Ladakh do XXI wieku.

Za jedną z potencjalnych barier nauczania można uważać barierę językową, bowiem wolontariusze nauczają po angielsku. Jednak wielu z nich prze- 
konało się naocznie, że przynajmniej wśród uczniów szkoły Spring Dales nie jest to żadna przeszkoda. Znajomość angielskiego jest wśród tamtejszej młodzieży lepsza niż w wielu wiejskich obszarach u nas. Niebezpieczniejsze od kłopotów językowych mogą być różnice kulturowe prowadzące do nieporozumień, i to muszą mieć na uwadze zwłaszcza nauczający (Cushner i Brennan, 2007).

Trzecim obszarem działalności ruchu Brontosaurus jest pomoc w rozbudowie szkoły. Pomagają architekci i budowniczowie, i właśnie tu skierowana jest główna część zgromadzonych środków finansowych. Ruch stara się nie sprzeniewierzyć swoim ekologicznym zasadom i przekonuje miejscowych do budowania z przynajmniej częściowym wykorzystaniem dawnych metod, które są bardziej przyjazne dla środowiska aniżeli nowoczesne budownictwo. Za nowoczesny uważany jest dzisiaj w Ladakhu dom z betonu. Miejscowa ludność nabrała przekonania, że można w ten sposób budować szybko niezwykle trwałe budynki. Nie przeszkadza im, że są droższe i mają gorsze cechy izolacyjne. Nic w tym dziwnego, ponieważ podobne zjawisko występowało często także w wielu wiejskich regionach w Europie. Beton oznaczał tu i tam wyższy status, podczas gdy słoma jest synonimem cywilizacyjnego zacofania. Można to jednak zmienić - przykładem jest Europa, gdzie aktualnie nowocześnie wykonana słomiana strzecha jest droższa od przemysłowo wyprodukowanych dachówek.

\section{Jak pomagać, by nie szkodzić?}

Wolontariat jest charakterystycznym zjawiskiem drugiej połowy XX wieku i początku XXI wieku. Jest to działalność pozytywnie oceniana ze wszystkich aspektów, w pełnej zgodzie z ideałami humanizmu i braterstwa między ludźmi całego świata. Bogatsi i zasobniejsi dzielą się z tymi, którzy mają mniej cóż może być bardziej szlachetnego? Wolontariusze z krajów rozwiniętych zaspokajają swoje potrzeby poznawania świata z dobrym uczuciem jednoczesnego pomagania tym najbardziej potrzebującym (Palacios, 2010). A jeżeli przedmiotem wolontariatu jest edukacja, to jeszcze lepiej. Ale czy naprawdę? Czy wolontariat nie ma też negatywnych konsekwencji?

Okazuje się, że są również negatywne skutki. W pewnych okolicznościach pomoc może zaszkodzić, pomimo pierwszoplanowych bezpośrednich korzyści. Może negatywnie wpływać na stosunki międzyludzkie miejscowego społeczeństwa. Może np. prowadzić do fałszywego wyobrażenia, że ludzie z Zachodu opływają we wszystko, i wzmacniać roszczeniowe postawy wśród 
tubylców. Może też naruszać naturalną hierarchię społeczną, deprawować poczucie wartości własnej kultury itp. (Talbot, 2015). A w samej zbitce pojęciowej turystyki wolontariatu - turystyka może przeważyć nad wolontariatem (Gutentag, 2009).

Mając to na uwadze, czescy przedstawiciele ruchu Brontosaurus w Himalajach postanowili zminimalizować to ryzyko. Działalność czeskich wolontariuszy ma być naprawdę skuteczna i ma przynosić jak największy pożytek dla miejscowej ludności. Aby nie było to tylko zaspokojenie dobrego samopoczucia „białego człowieka”, że pomaga biednym spoza jego cywilizacji, nie bacząc na to, że taka pomoc nieraz przynosi więcej problemów niż korzyści. Decydując się na włączenie do pomocy w edukacji w Ladakhu, czescy wolontariusze przyjęli kilka zasad, które powinny zapobiec większości negatywnych wpływów.

Ideą przewodnią pomocy Ladakhu od początku jest motto, które dziś widnieje na stronach internetowych ruchu Brontosaurus:

„Życie mieszkańców Małego Tybetu nieuchronnie zmierza ku nowoczesności. Aby tamtejsi ludzie nadal mogli korzystać z tego, co najlepsze w ich pierwotnej kulturze, musimy im pomóc przez odpowiednie wykształcenie. Dzięki temu ich kultura może być dla nas inspiracją również w przyszłości" (Brontosaurus v Himálájích, 2017).

Cała działalność organizacji Brontosaurus w Himalajach kieruje się następującymi zasadami:

1. Dążenie do poprawy poziomu wykształcenia jest postulatem miejscowej ludności. Dlatego też o miejscowej szkole decyduje miejscowe społeczeństwo, a czescy wolontariusze starają się tylko pomagać przy wypełnianiu tych dążeń.

2. Czescy wolontariusze nie wyręczają miejscowej ludności. Nie nauczają, podczas kiedy miejscowi tylko się przypatrują. Czesi asystują miejscowym nauczycielom i starają się im udostępnić wiedzę i doświadczenie pedagogiczne, ale podstawową pracę wykonują miejscowi nauczyciele.

3. Czesi nie finansują w pełni szkoły w Mulbekh. Najczęściej starają się o zapewnienie finansów z miejscowych źródeł (wkład z miejscowych źródeł ma najczęściej charakter znanej również u nas pracy społecznej), a jeżeli już coś rzeczywiście dają, to nie jest to darowizna, lecz finansowanie na zasadzie grantu.

4. Kształcenie dotyczy nie tylko dzieci, ale też dorosłych, najczęściej samych nauczycieli i kierownictwa szkoły. Tego podejmują się właśnie najczęściej czescy nauczyciele (Brontosaurus v Himálájích). 
Ważne jest, że wyżej opisane zasady - niewątpliwie bardzo szlachetne - nie są tylko szczytnymi hasłami z niewielkim odbiciem w rzeczywistości. Potwierdzają to uczestnicy czeskiej pomocy - od kierownika Sázela po szeregowych nauczycieli czy pomocników. I choć na pewno nie wszystkie zamierzenia się w stu procentach udały, powyższe zasady są przestrzegane i wydaje się, że z korzyścią dla mieszkańców regionu Ladakh.

Pewnym ograniczeniem może być fakt, że czescy nauczyciele nie znają miejscowego języka i prowadzą zajęcia po angielsku. Nie wszystkie miejscowe dzieci, ani też dorośli, znają ten światowy język numer jeden. Okazuje się jednak, że dzieci, które chodzą do szkoły Spring Dales, nie mają problemu językowego. Czescy nauczyciele, którzy prowadzili tam zajęcia, potwierdzają dobrą znajomość angielskiego przez wszystkich tamtejszych uczniów. A różnice kulturowe, powodujące czasem drobne nieporozumienia, nie są tego typu, aby uniemożliwiały międzykontynentalną współpracę. Okazuje się, że Ladakh nie jest dziś już tak odizolowaną częścią świata, jaką był jeszcze 2030 lat temu. Świadczy o tym fakt, że „czeska” szkoła w Mulbekh nie jest jedyną inicjatywą, którą rozwinięte kraje Europy i Ameryki Północnej realizują w ramach pomocy rozwojowej. W Ladakhu działa kilka innych organizacji pozarządowych. Przeważnie zajmują się ochroną środowiska, np. ochroną przed wyginięciem śnieżnej pantery. W kształceniu biorą udział m.in. Druk Kadma Karpo School (Szkoła Białego Lotosu) inicjowana i popierana przez tybeckiego Dalajlamę oraz SECMOL - Students' Educational Cultural Movement of Ladakh (Edukacyjno-Kulturowy Ruch Studentów Ladakhu) założony w 1988 roku przez absolwentów uniwersytetów z Ladakhu, którzy po studiach wrócili w rodzinne strony i starają się podnieść poziom wykształcenia miejscowej młodzieży. SECMOL jest m.in. partnerem w projekcie La Ngompo. Oprócz samych wolontariuszy do regionu przyjeżdża też coraz więcej turystów, i to także zmniejsza izolację Ladakhu. Przyjazdy turystów to jednak osobny temat (Michaud, 1991).

\section{Zakończenie}

Na zakończenie można się pokusić o podsumowanie dotychczasowej działalności czeskich wolontariuszy w Ladakhu. Generalna ocena wypada na pewno pozytywnie. Część z wolontariuszy, którzy od 2008 roku, a więc już w ciągu 10 lat, przewinęli się przez szkołę w Mulbekh, rzeczywiście można uznać za „humanitarnych turystów”, dla których poznawanie świata jest nieraz ważniejsze niż pomoc humanitarna, ale to nie neguje faktu, że rzeczywiście 
pomagają i to bezinteresownie, ponosząc w związku z tym nieraz niemałe koszty własne. Praca w szkole jest rzeczywistym wolontariatem, wykonywana jest za darmo, w wolnym czasie, a koszty transportu i wyżywienia są ponoszone przez samych uczestników. Większość czeskich wolontariuszy z ruchu Brontosaurus na pewno pomaga w Mulbekh z przekonania o pożyteczności pomocy w tej właśnie formie. Projekt poszerza możliwości kształcenia przynajmniej dla części miejscowych dzieci, a to, że szkołę prowadzi miejscowa społeczność i pracują w niej miejscowi nauczyciele, jest gwarancją, że szkoła ma szansę istnieć nawet w sytuacji, gdyby pomocy z zewnątrz zabrakło, oraz tego, że treści nauczane w szkole są dla miejscowej młodzieży naprawdę przydatne i nie są niezgodne $\mathrm{z}$ ich rodzimą kulturą.

\section{Bibliografia}

Bray, J. 1985. A History of the Moravian Church in India. W: Himalayan Mission. Leh: Moravian Church.

Brontosaurus v Himálajích. 2017. www.brontosaurusvhimalajich.cz (31.05.2017).

Callanan, M. and Thomas, S. 2005. Volunteer tourism. W: Novelli, M. red. Niche tourism: contemporary issues, trends and cases. Oxford: Elsevier Butterworth-Heinemann.

Cushner, K. and Brennan, S. 2007. The value of learning to teach in another culture. W: Cushner K. and Brennan S. red. Intercultural student teaching: A bridge to global competence. Lanham, MD: Rowman \& Littlefield Education, pp. 1-12.

Guttentag, D. A. 2009. The Possible Negative Impacts of Volunteer Tourism. International Journal of Tourism Research. 11, pp. 537-551.

Keatinge, H. 1993. The road to Leh. Aramco World. 44 (4), ss. 8-17.

Lamb, A. 1973. The Sino-Indian Border in Ladakh. W: Asian Publication.

Series 3. Canberra: Australian National University Press.

Michaud, J. 1991. A social anthropology of tourism in Ladakh, India. Annals of Tourism Research. 18 (4), pp. 605-621.

Palacios C. M., 2010. Volunteer tourism, development and education in post-colonial world: conceiving global connections beyond aid. Journal of Sustainable Tourism. 18 (10), pp. 861-887.

Prem Singh, J. 1994. Tourism in Ladakh Himalaya. New Delhi: Indus Publishing Company. 
Sarre, P. and Jehlicka, P. 2007. Environmental movements in space-time: the Czech and Slovak republics from Stalinism to post-socialism. Transactions of the Institute of British Geographers. 32 (3), pp. 346-362.

Snellgrove, D. and Skorupski, T. 1977. The Cultural Heritage of Ladakh. Warminster: Aris and Phillips.

Talbot, M. 2015. The negative impacts of volunteering: a qualitative case study of one UK Scout group. Voluntary Sector Review. 6 (2), pp. 209-220.

\title{
Intercultural education at a long distance: educational and ecological activities of Czech volunteers in Ladakh
}

\begin{abstract}
The paper presents educational activities of Czech ecologist activists, members of the Brontosaurus movement, who have helped to build a school in a village in Ladakh in Northern India. They teach there as well-predominantly local teachers. The private school under the patronage of the Czech organization has significantly improved the educational offer in the village of Mulbekh and its vicinity. In spite of its availability only for some local children, the school educates using more and more modern and more effective educational methods. Czech volunteers are aware of possible threats resulting from a cultural distance. Therefore, they try to act according to exactly specified rules, which should minimize these problems.
\end{abstract}

Keywords: intercultural education, volunteering, volunteer education, cultural distance, Czechs in the Himalaya, Ladakh

Translated by Tadeusz Siwek and Zuzana Hartmannová 